Review

\title{
Constituents and Pharmacological Activities of Myrcia (Myrtaceae): A Review of an Aromatic and Medicinal Group of Plants
}

\author{
Márcia Moraes Cascaes ${ }^{1}$, Giselle Maria Skelding Pinheiro Guilhon ${ }^{1, *}$, \\ Eloisa Helena de Aguiar Andrade ${ }^{1}$, Maria das Graças Bichara Zoghbi ${ }^{2}$ and \\ Lourivaldo da Silva Santos ${ }^{1}$ \\ 1 Programa de Pós-graduação em Química, Universidade Federal do Pará, \\ Belém 66075-110, PA, Brazil; E-Mails: cascaesmm@gmail.com (M.M.C.); \\ eloisandrade@ufpa.br (E.H.A.A.); 1ss@ufpa.br (L.S.S.) \\ 2 Museu Paraense Emílio Goeldi, Belém 66040-170, PA, Brazil; E-Mail: gracazoghbi@gmail.com \\ * Author to whom correspondence should be addressed; E-Mail: giselle@ufpa.br; \\ Tel.: +5591-3201-8099; Fax: +5591-3201-7635.
}

Academic Editor: Marcello Iriti

Received: 13 August 2015 / Accepted: 25 September 2015 / Published: 9 October 2015

\begin{abstract}
Myrcia is one of the largest genera of the economically important family Myrtaceae. Some of the species are used in folk medicine, such as a group known as "pedra-hume-caá" or "pedra-ume-caá" or "insulina vegetal" (insulin plant) that it is used for the treatment of diabetes. The species are an important source of essential oils, and most of the chemical studies on Myrcia describe the chemical composition of the essential oils, in which mono- and sesquiterpenes are predominant. The non-volatile compounds isolated from Myrcia are usually flavonoids, tannins, acetophenone derivatives and triterpenes. Anti-inflammatory, antinociceptive, antioxidant, antimicrobial activities have been described to Myrcia essential oils, while hypoglycemic, anti-hemorrhagic and antioxidant activities were attributed to the extracts. Flavonoid glucosides and acetophenone derivatives showed aldose reductase and $\alpha$-glucosidase inhibition, and could explain the traditional use of Myrcia species to treat diabetes. Antimicrobial and anti-inflammatory are some of the activities observed for other isolated compounds from Myrcia.
\end{abstract}

Keywords: Myrcia; volatiles; non-volatiles; biological activities 


\section{Introduction}

Myrtaceae Juss. is the ninth largest flowering plant family; it includes trees and shrubs with centers of diversity in the wet tropics, particularly in South America, Australia and Tropical Asia, distributed in 132 genera and 5671 species [1,2]. It also represents one of the largest families of the Brazilian flora, where 23 genera and 1034 species occur distributed in all regions and vegetal formations of the country [1-4]. Economically, Myrtaceae is a very important family; some species are cultivated, such as Eucalyptus spp., from which the wood is used to produce paper, lamppost and charcoal; other species are ornamental and some are used as spices, such as Syzygium aromaticum (L.) Merr. \& L.M.Perry, known as "cravo-da-índia" or clove. Several species produce edible fruits that are used to make juice, jelly and sweets, such as Psidium guajava L. ("goiabeira" and "guava"), Myrciaria cauliflora (Mart.) O.Berg ("jabuticabeira”), Eugenia uniflora L. ("pitangueira”), Syzygium spp. ("jambo"), but not all are cultivated. Myrtaceae species are also used in folk medicine to treat several diseases, especially gastrointestinal disorders, hemorrhagic and infectious diseases with an action that is probably related to its astringents properties [5].

Myrcia sensu lato or Myrcia s.1. (sensu Lucas et al., 2011) is now considered a large genus taken in a loose sense, composed of four traditional genera (Myrcia DC., Marlierea Cambess, Calyptranthes Sw. and Gomidesia O.Berg), comprising 753 species [1], that are now in process of synonimization based on recent molecular findings [6-8]. According to Rosario and coworkers, many species of these four genera found in the Amazon still need phylogenetic analysis [9].

There are 260 listed Myrcia species in Brazil found in different biomes and in all five regions of the country [2]. Myrcia species are an important source of essential oils and some species have been used in folk medicine. In the present work, traditional uses, identified volatile and non-volatile compounds, and the pharmacological activities of crude extracts, essential oils and isolated compounds from Myrcia sensu stricto are reviewed.

\section{Traditional Uses}

Some Myrcia species have been used in folk medicine, usually as infusions, for a long time [10-13]. The most cited traditional use of Myrcia species is related to a small group of Myrtaceae known in Brazil as "pedra-hume-caá", "pedra-ume-caá" or "insulina vegetal" (insulin plant). The leaves or whole plant infusions of these plants are used to treat diabetes; this group of plants includes Myrcia (M.) punicifolia (Kunth) DC., M. speciosa (Amsh.) Mc Vaugh, M. amazonica DC., M. citrifolia (Aubl.) Urb., M. guianensis (Aubl.) DC., M. multiflora (Lam.) DC., M. salicifolia DC., M. sylvatica (G. Mey) DC., M. uniflora DC. besides Eugenia punicifolia (Kunth) DC. [14,15]. Myrcia uniflora is sold as a dry extract in capsules or as tinctures for the treatment of diabetes. "Pedra-ume-caá" is also used to treat diarrhea, enteritis, hemorrhage and aphtha [10] and M. salicifolia is good for cold sores and mouth ulcers [16]. Other Myrcia species have traditional uses: Myrcia bracteata DC. is used to treat dyspepsia [13]; M. ovata Cambess. is used on the treatment of gastric illness, gastritis and diarrhea [17]; and the inhabitants of the Amazon region use the macerated leaves of M. guianensis to neutralize snake venoms [18]. 


\section{Volatiles}

Most chemical and biological studies on Myrcia deal with the essential oils obtained from these species [19]. Major compounds from the essential oils of Myrcia ( $>5 \%)$ are summarized in Table 1, together with the classes and the total of the identified compounds, in accordance to literature.

Table 1. Relative abundance $(>5 \%)$ of the constituents in the essential oils from Myrcia species.

\begin{tabular}{|c|c|c|c|}
\hline Species & $\begin{array}{l}\text { Part of the } \\
\text { Plant } \\
\text { (Yield: } v / w)\end{array}$ & $\begin{array}{l}\text { Compounds (Relative Abundance, } \%>5 \text { ) } \\
\text { Classes of Substances; Total }\end{array}$ & Ref. \\
\hline $\begin{array}{l}\text { M. acuminatissima } \\
\text { O.Berg }\end{array}$ & $\begin{array}{l}\text { Fresh leaves } \\
\quad(0.12 \%)\end{array}$ & $\begin{array}{l}\beta \text {-pinene (5.0), linalool (22.3), terpinen-4-ol (5.2), } \\
\beta \text {-caryophyllene (8.1), spathulenol (7.5), } \\
\text { caryophyllene oxide (5.5) } \\
\text { MH: } 13.9 \% \text {, OM: } 35.1 \% \text {, SH: } 15.7 \% \text {, OS: } 28.0 \% \text {, T: } 97.0 \%\end{array}$ & {$[20]$} \\
\hline \multirow{2}{*}{$\begin{array}{l}\text { M. alagoensis } \\
\text { O.Berg }\end{array}$} & $\begin{array}{l}\text { Fresh leaves } \\
\qquad(0.3 \%)\end{array}$ & $\begin{array}{l}\beta \text {-caryophyllene }(7.9) \text {, germacrene } \mathrm{D}(11.1), \\
\text { germacrene B }(26.7),(2 E, 6 E) \text {-farnesoic acid }(7.3) \\
\text { S: } 79.9 \%, \mathrm{~T}: 80.5 \%\end{array}$ & {$[21]$} \\
\hline & $\begin{array}{l}\text { Dry leaves } \\
\quad(0.4 \%)\end{array}$ & $\begin{array}{l}\beta \text {-caryophyllene (7.8), germacrene D (6.4), } \delta \text {-cadinene (5.4), } \\
\text { selina-3,7(11)-diene (5.4), germacrene B (23.1) } \\
\text { S: } 75.4 \%, \text { T: } 75.5 \%\end{array}$ & {$[21]$} \\
\hline \multirow{2}{*}{ M. amazonica DC. } & $\begin{array}{c}\text { Fresh leaves } \\
(0.65 \%)\end{array}$ & $\begin{array}{l}\text { germacrene D (10.09), germacrene B (9.59), } \\
\text { 1-epi-cubenol (20.22), } \alpha \text {-muurolol }(6.21)\end{array}$ & {$[22]$} \\
\hline & $\begin{array}{c}\text { Dry leaves } \\
(0.96 \%)\end{array}$ & $\begin{array}{l}\text { germacrene D (16.56), germacrene B (11.09), } \\
\text { 1-epi-cubenol (14.72) }\end{array}$ & {$[22]$} \\
\hline $\begin{array}{l}\text { M. arborescens } \\
\text { O.Berg }\end{array}$ & $\begin{array}{l}\text { Fresh leaves } \\
\qquad(0.2 \%)\end{array}$ & $\begin{array}{l}\alpha \text {-muurolol (6.2), caryophyllene oxide (26.3), spathulenol } \\
\text { (8.9), globulol (15.9), 5-epi-7-epi- } \alpha \text {-eudesmol (5.9) } \\
\text { S: 94.8\%, T: } 96.2 \%\end{array}$ & [23] \\
\hline $\begin{array}{l}\text { M. bombycina } \\
\text { (O.Berg) Nied. }\end{array}$ & $\begin{array}{l}\text { Fresh leaves } \\
\qquad(0.95 \%)\end{array}$ & $\begin{array}{l}\alpha \text {-pinene (23.9), } \beta \text {-pinene (12.4), limonene (7.0), } \\
\gamma \text {-eudesmol (7.8) } \\
\text { MH: } 53.0 \% \text {, OM: } 5.4 \% \text {, SH: } 8.0 \% \text {, OS: } 24.0 \%, \text { T: } 93.5 \%\end{array}$ & {$[20]$} \\
\hline \multirow{4}{*}{ M. bracteata DC. } & $\begin{array}{l}\text { Leaves } \\
(0.71 \%)\end{array}$ & $\begin{array}{l}\alpha \text {-bisabolol oxide (10.37), } \alpha \text {-bisabolol (45.86) } \\
\text { SH: } 13.76 \% \text {, OS: } 63.49 \%, \text { S: } 77.25 \%\end{array}$ & {$[24]$} \\
\hline & $\begin{array}{l}\text { Leaves and } \\
\text { fine stems } \\
(0.1 \%)^{\mathrm{a}}\end{array}$ & $(E)$-nerolidol $(80.8)$ & {$[25]$} \\
\hline & $\begin{array}{l}\text { Leaves and } \\
\text { fine stems } \\
(0.3 \%)^{\mathrm{a}}\end{array}$ & (E)- $\beta$-farnesene (33.9), $\beta$-curcumene (9.8), $\beta$-bisabolol (8.2) & {$[25]$} \\
\hline & $\begin{array}{c}\text { Leaves and } \\
\text { fine stems } \\
(0.1 \%)^{\mathrm{a}}\end{array}$ & germacrene B (8.8), spathulenol (31.0) & {$[25]$} \\
\hline
\end{tabular}


Table 1. Cont.

\begin{tabular}{|c|c|c|c|}
\hline Species & $\begin{array}{l}\text { Part of the } \\
\text { Plant } \\
\text { (Yield: } v / w)\end{array}$ & $\begin{array}{l}\text { Compounds (Relative Abundance, } \%>5 \text { ) } \\
\text { Classes of Substances; Total }\end{array}$ & Ref. \\
\hline \multirow{4}{*}{$\begin{array}{l}\text { M. cuprea } \\
\text { (O.Berg) Kiaersk. }\end{array}$} & $\begin{array}{l}\text { Leaves } \\
(<0.05 \%)\end{array}$ & $\begin{array}{l}\beta \text {-caryophyllene (9.57), } \alpha \text {-humulene }(7.03), \\
\gamma \text {-selinene }(21.75), \alpha \text {-selinene }(11.84), \\
(Z) \text { - } \alpha \text {-bisabolene }(9.51),(E, E) \text { - } \alpha \text {-farnesene }(10.52) \\
\text { SH: } 82.41 \%, \text { S: } 82.41 \%, \text { OTH: } 11.02 \%\end{array}$ & {$[24]$} \\
\hline & $\begin{array}{l}\text { Leaves and } \\
\text { fine stems } \\
(0.3 \%)^{\mathrm{a}} \\
\end{array}$ & myrcene (48.1), $\beta$-caryophyllene (19.9), $\delta$-cadinene (6.9) & {$[25]$} \\
\hline & $\begin{array}{l}\text { Leaves and } \\
\text { fine stems } \\
(0.1 \%)^{\mathrm{a}} \\
\end{array}$ & $\alpha$-pinene (15.9), myrcene (19.2), $\beta$-caryophyllene (39.1) & {$[25]$} \\
\hline & $\begin{array}{l}\text { Leaves and } \\
\text { fine stems } \\
(>0.1 \%)^{\mathrm{a}} \\
\end{array}$ & $\begin{array}{l}\beta \text {-caryophyllene (38.1), germacrene D (21.8), } \\
\text { germacrene B (19.5) }\end{array}$ & {$[25]$} \\
\hline \multirow{4}{*}{$\begin{array}{l}\text { M. fallax (Rich.) } \\
\text { DC. }\end{array}$} & $\begin{array}{l}\text { Leaves } \\
(0.09 \%)\end{array}$ & $\begin{array}{l}\alpha \text {-pinene (7.68), } \beta \text {-pinene (11.88), } \beta \text {-elemene (11.21), } \\
\beta \text {-caryophyllene (5.55), selin-11-en-4 } \alpha \text {-ol (7.56) } \\
\text { MH: } 22.29 \%, \text { M: } 24.02 \% \text {, SH: } 41.83 \% \text {, OS: } 24.20 \% \text {, } \\
\text { S: } 66.03 \%\end{array}$ & {$[24]$} \\
\hline & $\begin{array}{l}\text { Leaves } \\
(0.25 \%)\end{array}$ & $\begin{array}{l}\alpha \text {-pinene (7.7), } \beta \text {-pinene (6.9), } \beta \text {-caryophyllene (6.0), } \\
\text { carotol (9.9), guaiol (31.0) } \\
\text { T: } 83.4 \%\end{array}$ & {$[26]$} \\
\hline & $\begin{array}{l}\text { Flowers } \\
(0.30 \%) \\
\end{array}$ & $\begin{array}{l}\alpha \text {-pinene (6.0), guaiol (27.5), aristolene (24.5) } \\
\text { T: } 83.2 \%\end{array}$ & {$[26]$} \\
\hline & $\begin{array}{c}\text { Fresh leaves } \\
(0.25 \%) \\
\end{array}$ & $\begin{array}{l}\alpha \text {-bisabolol (83.8) } \\
\text { SH: } 7.2 \% \text {, OS: } 86.5 \%, \mathrm{~T}: 94.3 \%\end{array}$ & {$[20]$} \\
\hline M. aff. fosteri Croat & Leaves & $\begin{array}{l}\beta \text {-bisabolol oxide (19.2), } \alpha \text {-bisabolol (19.2), } \\
\text { bisabolol oxide B (7.0), undeca-4,6-diene (5.4) } \\
\text { SH: } 8.2 \% \text {, OS: } 65.9 \%, \mathrm{~T}: 76.7 \%\end{array}$ & {$[27]$} \\
\hline $\begin{array}{l}\text { M. glabra (O.Berg) } \\
\text { D.Legrand }\end{array}$ & $\begin{array}{l}\text { Fresh leaves } \\
\qquad(0.11 \%)\end{array}$ & $\begin{array}{l}\alpha \text {-copaene (6.1), } \beta \text {-caryophyllene (9.5), } \beta \text {-selinene (5.8), } \\
\alpha \text {-selinene (9.4), valerianol (13.2) } \\
\text { SH: } 54.4 \% \text {, OS: } 27.4 \% \text {, OTH: 9.4\%, T: } 92.0 \%\end{array}$ & {$[20]$} \\
\hline $\begin{array}{l}\text { M. hatschbachii } \\
\text { D.Legrand }\end{array}$ & $\begin{array}{l}\text { Fresh leaves } \\
\qquad(0.1 \%)\end{array}$ & $\begin{array}{l}\text { germacrene D (6.4\%), } \gamma \text {-cadinene (8.1), } \alpha \text {-cadinol (6.1), } \\
\beta \text {-caryophyllene }(23.3) \\
\text { S: } 95.2 \% \text {, T: } 97.9 \%\end{array}$ & {$[23]$} \\
\hline $\begin{array}{l}\text { M. lageana } \\
\text { D.Legrand }\end{array}$ & $\begin{array}{c}\text { Fresh leaves } \\
(0.3 \%)\end{array}$ & $\begin{array}{l}(E) \text {-nerolidyl acetate (25.3), germacrene D (23.4) } \\
\text { S: } 98.5 \%, \text { T: } 99.3 \%\end{array}$ & {$[23]$} \\
\hline
\end{tabular}


Table 1. Cont.

\begin{tabular}{|c|c|c|c|}
\hline Species & $\begin{array}{l}\text { Part of the Plant } \\
\text { (Yield: } v / w)\end{array}$ & $\begin{array}{l}\text { Compounds (Relative Abundance, } \%>5 \text { ) } \\
\text { Classes of Substances; Total }\end{array}$ & Ref. \\
\hline \multirow{3}{*}{$\begin{array}{l}\text { M. laruotteana } \\
\text { Camb. }\end{array}$} & $\begin{array}{l}\text { Unripe fruits } \\
\qquad(0.3 \%)\end{array}$ & $\begin{array}{l}\text { spathulenol (5.4), globulol (6.3), } \alpha \text {-bisabolol oxide B (11.5), } \\
\alpha \text {-bisabolol (23.6), globulol (6.3), } \\
(2 E, 6 E) \text {-methyl farnesoate }(5.8) \\
\text { SH: } 5.8 \% \text {, OS: } 75.8 \% \text {, T: } 82.8 \%\end{array}$ & [28] \\
\hline & Leaves $(0.05 \%)$ & $\begin{array}{l}\text { spathulenol (7.3), globulol (6.2), guaiol (6.1), } \\
\text { 1-epi-cubenol (5.0), } \alpha \text {-cadinol (8.0), } \alpha \text {-bisabolol (20.7), } \\
\text { 14-hydroxy- } \alpha \text {-muurolene (19.9) } \\
\text { SH: } 10.2 \% \text {, OS: } 79.6 \%, \text { T: } 90.4 \%\end{array}$ & [29] \\
\hline & Flowers $(0.07 \%)$ & $\begin{array}{l}\text { spathulenol (8.6), globulol (6.6), guaiol (7.7), } \\
\text { 1-epi-cubenol (5.0), } \alpha \text {-cadinol (6.5), } \alpha \text {-bisabolol (28.1), } \\
\text { 14-hydroxy- } \alpha \text {-muurolene (13.7) } \\
\text { SH: } 9.1 \% \text {, OS: } 83.1 \% \text {, T: } 95.5 \%\end{array}$ & [29] \\
\hline \multirow{2}{*}{$\begin{array}{l}\text { M. multiflora } \\
\text { (Lam) DC. }\end{array}$} & Leaves $(1.16 \%)$ & $\begin{array}{l}\alpha \text {-gurjunene (6.40), } \beta \text {-caryophyllene (10.72), } \gamma \text {-selinene (5.12), } \\
\alpha \text {-selinene (8.67), selin-11-en-4 } \alpha \text {-ol (10.67) } \\
\text { MH: } 6.14 \% \text {, OS: } 5.23 \% \text {, M: } 11.37 \%, \text { SH: } 53.91 \%, \\
\text { OS: } 17.57 \%, \text { S: } 71.48 \%\end{array}$ & {$[24]$} \\
\hline & $\begin{array}{l}\text { Fresh leaves } \\
\quad(0.20 \%)\end{array}$ & $\begin{array}{l}\beta \text {-caryophyllene (7.5), germacrene D ( } 8.7) \text {, } \\
\text { bicyclogermacrene }(6.3), \delta \text {-cadinene }(5.2) \text {, } \\
\text { MW } 222(7.4) \text {, cubenol }(5.9) \\
\text { SH: } 44.9 \% \text {, OS: } 32.3 \% \text {, n.i.: } 5.9 \% \text {, T: } 87.5 \%\end{array}$ & {$[20]$} \\
\hline \multirow{3}{*}{$\begin{array}{l}\text { M. myrtillifolia } \\
\text { DC. }\end{array}$} & Leaves $(0.14 \%)^{b}$ & $\begin{array}{l}\alpha \text {-pinene (80.4), } \alpha \text {-terpineol (7.0) } \\
\text { MH: } 85.4 \%, \text { OM: } 13.0 \%, \text { T: } 99.7 \%\end{array}$ & {$[30]$} \\
\hline & Flowers $(0.26 \%)^{b}$ & $\begin{array}{l}\alpha \text {-pinene (76.2) } \\
\text { MH: 77.1\%, OM: 9.9\%, T: } 88.8 \%\end{array}$ & {$[30]$} \\
\hline & Fruits $(0.37 \%)^{b}$ & $\begin{array}{l}\text { a-pinene }(88.1) \\
\text { MH: } 91.9 \%, T: 96.8 \%\end{array}$ & {$[30]$} \\
\hline $\begin{array}{l}\text { M. obtecta } \\
\text { (O.Berg) } \\
\text { Kiaersk. }\end{array}$ & $\begin{array}{l}\text { Fresh leaves } \\
\qquad(0.1 \%)\end{array}$ & $\begin{array}{l}\alpha \text {-pinene (7.2), ar-curcumene (19.0), } \beta \text {-bisabolene (8.5), } \\
\alpha \text {-copaene (8.0), } \alpha \text {-humulene (6.2) } \\
\text { M: } 16.2 \%, \text { S: } 79.1 \%, \text { T: } 95.3 \%\end{array}$ & {$[23]$} \\
\hline \multirow{2}{*}{$\begin{array}{l}\text { M. obtecta } \\
\text { (O.Berg) } \\
\text { Kiaersk. }\end{array}$} & Leaves $(0.01 \%)^{b}$ & $\begin{array}{l}\alpha \text {-terpineol (11.2), } \alpha \text {-guainene (5.8), } \\
\text { trans-calamenene (29.3), 1-epi-cubenol (5.6) } \\
\text { M: } 16.7 \% \text {, SH: } 56.4 \% \text {, OS: } 20.9 \% \text {, T: } 95.6 \%\end{array}$ & [31] \\
\hline & Flowers (n.i.) & $\begin{array}{l}\text { methyl salicilate }(88.2) \\
\text { T: } 97.9 \%\end{array}$ & [31] \\
\hline $\begin{array}{l}\text { M. oligantha } \\
\text { O.Berg }\end{array}$ & $\begin{array}{l}\text { Fresh leaves } \\
\qquad(0.1 \%)\end{array}$ & $\begin{array}{l}\delta \text {-cadinene (17.9), 1-epi-cubenol (7.2), cubenol (5.7), } \\
\beta \text {-caryophyllene (6.5), caryophyllene oxide (5.4), } \\
\text { bicyclogermacrene (8.3), spathulenol (10.2) } \\
\text { S: } 96.8 \%, \text { T: } 99.9 \%\end{array}$ & [23] \\
\hline \multirow{2}{*}{$\begin{array}{l}\text { M. ovata } \\
\text { Cambess. }\end{array}$} & Leaves $(0.9 \%)$ & $\begin{array}{l}\text { neral (35.8), geranial (50.4) } \\
\mathrm{T}: 92.1 \%\end{array}$ & {$[17,32]$} \\
\hline & $\begin{array}{c}\text { Leaves } \\
(1.27 \% ; w / w)\end{array}$ & OM: $91.78 \%, \mathrm{~T}: 93.55 \%$ & [33] \\
\hline
\end{tabular}


Table 1. Cont.

\begin{tabular}{|c|c|c|c|}
\hline Species & $\begin{array}{l}\text { Part of the } \\
\text { Plant } \\
\text { (Yield: } v / w)\end{array}$ & $\begin{array}{l}\text { Compounds (Relative Abundance, } \%>5 \text { ) } \\
\text { Classes of Substances; Total }\end{array}$ & Ref. \\
\hline M. pubiflora DC. & $\begin{array}{l}\text { Fresh leaves } \\
\qquad(1.1 \%)\end{array}$ & $\begin{array}{l}\text { tricyclene (5.27), 1,8-cineole (5.35), } \\
\text { caryophyllene oxide (22.16), mustakone (11.34) } \\
\text { T: } 72.7 \%\end{array}$ & {$[34]$} \\
\hline M. pubipetala Miq. & $\begin{array}{l}\text { Fresh leaves } \\
\qquad(0.1 \%)\end{array}$ & $\begin{array}{l}\text { germacrene D (7.2), } \beta \text {-caryophyllene (13.3), } \\
\text { bicyclogermacrene (25.2), spathulenol (31.7), } \\
n \text {-heneicosane (14.9) } \\
\text { OTH: } 14.9 \%, \text { S: } 84.8 \% \text {, T: } 99.7 \%\end{array}$ & {$[23]$} \\
\hline $\begin{array}{l}\text { M. richardiana } \\
\text { (O.Berg) Kiaersk. }\end{array}$ & $\begin{array}{l}\text { Fresh leaves } \\
\qquad(0.1 \%)\end{array}$ & $\begin{array}{l}\beta \text {-caryophyllene (20.6), caryophyllene oxide (19.3), } \\
\alpha \text {-humulene (5.1), bicyclogermacrene (5.7) } \\
\text { S: } 90.0 \%, \text { T: } 90.0 \%\end{array}$ & [23] \\
\hline M. rostrata DC. & $\begin{array}{l}\text { Fresh leaves } \\
\qquad(0.2 \%)\end{array}$ & $\begin{array}{l}\delta \text {-cadinene (5.7), } \tau \text {-muurolol (5.1), caryophyllene oxide } \\
(13.1), \text { bicyclogermacrene }(6.8) \text {, spathulenol }(17.3) \\
\text { S: } 93.3 \%, \text { T: } 93.3 \%\end{array}$ & [23] \\
\hline \multirow{2}{*}{$\begin{array}{l}\text { M. rufipila } \\
\text { McVaugh }\end{array}$} & $\begin{array}{l}\text { Leaves } \\
(0.42 \%)^{a}\end{array}$ & $\begin{array}{l}\beta \text {-caryophyllene (7.07), } \gamma \text {-elemene (10.49), } \\
\text { germacrene D (9.09), bicyclogermacrene (7.49), } \\
\delta \text {-cadinene (7.36), germacrene B (6.70) } \\
\text { SH: } 72.35 \%, \text { OS: } 19.93 \%, \text { S: } 92.28 \%\end{array}$ & {$[24]$} \\
\hline & $\begin{array}{l}\text { Leaves } \\
(0.18 \%)^{a}\end{array}$ & $\begin{array}{l}\beta \text {-caryophyllene (5.66), germacrene D (10.31), } \\
\delta \text {-cadinene (10.12), } \alpha \text {-cadinol }(6.20) \\
\text { SH: } 65.87 \% \text {, OS: } 23.69 \%, \text { S: } 89.56 \%\end{array}$ & {$[24]$} \\
\hline \multirow{2}{*}{$\begin{array}{l}\text { M. salzmanni } \\
\text { O.Berg }\end{array}$} & Leaves (n.i.) ${ }^{b}$ & $\begin{array}{l}\beta \text {-caryophyllene (25.9), } \alpha \text {-humulene(12.9), MW } 222(11.7) \text {, } \\
\text { MW } 220 \text { (14.2), MW } 222(10.0) \\
\text { SH: } 49.2 \% \text {, OS: } 10.1 \% \text {, NI: } 36.2 \% \text {, T: } 95.5 \%\end{array}$ & {$[35]$} \\
\hline & Flowers (n.i.) & $\begin{array}{l}\beta \text {-caryophyllene (13.8), } \alpha \text {-humulene (10.9), MW } 222(10.0) \text {, } \\
\text { MW } 220 \text { (12.6), cis- } \beta \text {-elemone (6.2), MW } 222(7.1) \\
\text { SH: } 36.4 \% \text {, OS: } 20.1 \% \text {, NI: } 38.6 \% \text {, T: } 95.4 \%\end{array}$ & {$[35]$} \\
\hline $\begin{array}{l}\text { M. selloii (Spreng.) } \\
\text { N.Silveira }\end{array}$ & $\begin{array}{l}\text { Fresh leaves } \\
\qquad(0.5 \%)\end{array}$ & $\begin{array}{l}\text { germacrene D (6.7), } \delta \text {-cadinene }(14.5), \tau \text {-cadinol }(9.3), \\
\alpha \text {-cadinol (17.2), } \beta \text {-caryophyllene (9.0), } \\
\text { bicyclogermacrene }(10.2) \\
\text { S: } 99.2 \%, T: 99.9 \%\end{array}$ & [23] \\
\hline \multirow{3}{*}{$\begin{array}{l}\text { M. splendens (Sw.) } \\
\text { DC. }\end{array}$} & $\begin{array}{l}\text { Fresh leaves } \\
(0.44 \%) \\
\end{array}$ & $\begin{array}{l}\text { (Z)- } \alpha \text {-bisabolene (79.65) } \\
\text { SH: } 94.54 \%, \text { S: } 98.34 \%, \text { T: } 98.34 \%\end{array}$ & {$[36]$} \\
\hline & $\begin{array}{l}\text { Fresh stems } \\
\qquad(0.15 \%)\end{array}$ & $\begin{array}{l}\beta \text {-caryophyllene (23.8), germacrene } \mathrm{D}(25.3), \\
\text { bicyclogermacrene (7.1), caryophyllene oxide (10.5) } \\
\text { T: } 97.2 \%\end{array}$ & {$[37]$} \\
\hline & Leaves (n.i.) & $\begin{array}{l}\text { trans-2-hexenal (9.5), germacrene D (35.9), } \delta \text {-cadinene (5.8), } \\
\text { epi- } \alpha \text {-cadinol (6.8), valerianol (16.3) } \\
\text { SH: } 55.7 \% \text {, OS: } 31.8 \% \text {, T: } 96.9 \%\end{array}$ & {$[38]$} \\
\hline
\end{tabular}


Table 1. Cont.

\begin{tabular}{|c|c|c|c|}
\hline Species & $\begin{array}{l}\text { Part of the } \\
\text { Plant } \\
\text { (Yield: } v / w) \\
\end{array}$ & $\begin{array}{l}\text { Compounds (Relative Abundance, } \%>5 \text { ) } \\
\text { Classes of Substances; Total }\end{array}$ & Ref. \\
\hline \multirow{3}{*}{$\begin{array}{l}\text { M. sylvatica } \\
\text { (G.Mey) DC. }\end{array}$} & $\begin{array}{l}\text { Leaves and } \\
\text { fine stems } \\
(>0.1 \%)^{\mathrm{a}} \\
\end{array}$ & $\begin{array}{l}\text { spathulenol (13.8), caryophyllene oxide (16.6), } \\
\text { selin-11-en-4 } \alpha \text {-ol (24.7) }\end{array}$ & {$[25]$} \\
\hline & $\begin{array}{l}\text { Leaves and } \\
\text { fine stems } \\
(0.3 \%)^{\mathrm{a}}\end{array}$ & $\begin{array}{l}\text { cis-calamenene (30.1), } \alpha \text {-calacorene (11.5), } \\
\text { spathulenol (18.7) }\end{array}$ & {$[25]$} \\
\hline & $\begin{array}{l}\text { Leaves and } \\
\text { fine stems } \\
(>0.1 \%)^{\mathrm{a}}\end{array}$ & $\beta$-bisabolene (14.7), spathulenol (40.2) & {$[25]$} \\
\hline \multirow{8}{*}{$\begin{array}{l}\text { M. tomentosa } \\
\text { (Aubl.) DC. }\end{array}$} & $\begin{array}{l}\text { Aerial parts } \\
(0.54 \%)^{\mathrm{b}}\end{array}$ & $\begin{array}{l}\text { (E)- } \beta \text {-farnesene }(6.94), \gamma \text {-muurolene }(18.04) \text {, } \\
\text { bicyclogermacrene }(11.51) \text {, } \\
(2 E, 6 E) \text {-methyl farnesoate }(36.95) \\
\text { SH: } 47.22 \%, \text { OS: } 52.02 \%, \text { T: } 99.24 \%\end{array}$ & {$[39]$} \\
\hline & $\begin{array}{l}\text { Fresh flowers } \\
\qquad(0.31 \%)\end{array}$ & $\begin{array}{l}\text { spathulenol (7.36), globulol (5.97), (2Z,6Z)-farnesal (6.86), } \\
(2 Z, 6 Z) \text {-farnesol (10.65), (2E,6E)-farnesal (5.36), } \\
(2 E, 6 E) \text {-methyl farnesoate }(14.28) \text {, benzyl salicylate (5.99) } \\
\text { OS: } 46.69 \% \text {, OTH: } 24.61 \%, \mathrm{~T}: 72.71 \%\end{array}$ & {$[39]$} \\
\hline & $\begin{array}{l}\text { Stem bark } \\
(0.31 \%)\end{array}$ & $\begin{array}{l}(2 E, 6 E) \text {-methyl farnesoate }(14.39) \text {, } \\
\text { hexadecanoic acid }(22.05) \\
\text { SH: } 6.26 \% \text {, OS: } 9.06 \% \text {, OTH: } 60.4 \%, \mathrm{~T}: 76.27 \%\end{array}$ & {$[39]$} \\
\hline & $\begin{array}{l}\text { Leaves } \\
(0.1-0.8)^{\mathrm{b}}\end{array}$ & $\begin{array}{l}\text { spathulenol (18.35), globulol (7.66), } \\
(2 E, 6 E) \text {-methyl farnesoate }(46.38)\end{array}$ & {$[40]$} \\
\hline & $\begin{array}{l}\text { Leaves } \\
(0.1-0.8)^{\mathrm{b}}\end{array}$ & $\begin{array}{l}\gamma \text {-muurolene (14.20), bicyclogermacrene (14.38), } \\
\delta \text {-amorphene (18.83) }\end{array}$ & {$[40]$} \\
\hline & $\begin{array}{l}\text { Leaves } \\
(0.1-0.8)^{b}\end{array}$ & $\begin{array}{l}\gamma \text {-muurolene (6.62), bicyclogermacrene (8.04), } \\
\text { globulol (57.48) }\end{array}$ & {$[40]$} \\
\hline & $\begin{array}{c}\text { Leaves } \\
(0.1-0.8)^{\mathrm{b}}\end{array}$ & $\begin{array}{l}\gamma \text {-muurolene (7.67), bicyclogermacrene (5.85), } \\
(2 E, 6 E) \text {-methyl farnesoate }(60.69)\end{array}$ & {$[40]$} \\
\hline & $\begin{array}{l}\text { Leaves } \\
(0.1-0.8)^{\mathrm{b}}\end{array}$ & $\begin{array}{l}\beta \text {-caryophyllene (12.66), } \gamma \text {-muurolene (40.16), } \\
\text { bicyclogermacrene (13.74), } \delta \text {-amorphene }(6.31)\end{array}$ & {$[40]$} \\
\hline
\end{tabular}

M: Monoterpenes (hydrocarbons and oxygenated); S: Sesquiterpenes (hydrocarbons and oxygenated); MH: Monoterpene Hydrocarbons; OM: Oxigenated Monoterpenes; SH: Sesquiterpene Hydrocarbons; OS: Oxigenated Sesquiterpenes; OTH: Others; NI: not identified; T: total of the identified compounds; ${ }^{\text {a }}$ Different site of collection for a same species in a same reference; ${ }^{b}$ Studies of seasonal or circadian variations (oils with the highest $\mathrm{T}$ and measured yield is listed); n.i.: not informed; Ref.: Reference.

Leaves, flowers, stems, fruits of Myrcia can produce essential oils. Sesquiterpenes are the major compounds in most of these oils, although monoterpenes were identified in a higher amount than sesquiterpenes in the essential oil of M. acuminatissima and M. bombycina [20], one of the studied specimen of M. cuprea [25], M. myrtillifolia [30] and M. ovata [17,32,33]. The major compound of the essential oil of $M$. obtecta flowers of was methyl salicylate [31], and the most abundant compound of the essential oil of M. tomentosa stem bark was decanoic acid [39]. 
According to Alarcón and coworkers [26], the essential oils of M. fallax collected in Venezuela were different; leaves and flowers oils were rich on guaiol/carotol and guaiol/aritolone, respectively. Additionally, it was observed that the essential oils from M. falax collected in Venezuela were also different from the specimens from Brazil, in which those terpenes were not identified [20,24].

Siani and coworkers arranged the mono- and sesquiterpenes from 15 Neotropical Myrtaceae in accordance to their biosynthetic pathways; the species showed a heterogeneous composition, with a wide variation with respect to terpenoid structures, including bisabolene-type; no chemotaxonomical implications were found [41].

Seasonal variation studies have demonstrated that the essential oil of M. obtecta leaves did not exhibitet important differences on the composition, except for the flowering month, when $\alpha$-terpineol and trans-calamenene were detected on the highest amounts [31]. The essential oil of the leaves of $M$. tomentosa exhibited seasonal variation; it was observed that only nine of 44 compounds were identified in all samples, indicating a significant correlation between the climatic data, foliar nutrients and essential oil composition [39]. Cluster and Principal Component analysis indicated a high chemovariability within the essential oils of M. tomentosa [39]. The oil from M. salzmannii leaves showed qualitative and quantitative variations in the composition; only two compounds, $\beta$-caryophyllene and $\alpha$-humulene, were identified in all samples [35]. According to Zoghbi and coworkers, the essential oils of M. sylvatica show intraspecific variation [25].

\section{Biological and Antioxidant Activities of the Essential Oils of Myrcia Species and Their Major Constituents}

Several studies have shown the biological activities of Myrcia essential oils [19]. The number of published papers is growing every day.

\subsection{Anti-Inflammatory and Antinociceptive Effect}

Essential oils from M. ovata leaves (50-300 mg/ $\mathrm{kg}$ of oral doses) showed significant effect in acute pain and inflammation tests with no adverse effects and intoxication during the assays; according to the authors, these results provided initial evidence of the traditional use of this species [33].

The essential oil from the fresh leaves of M. pubiflora $(25,50$ and $100 \mathrm{mg} / \mathrm{kg}$ ) significantly reduced the number of writhing induced by acetic acid and the nociception in the second phase of formalin test; it exhibited inhibitory effect on carrageenan-induced response, it was ineffective inhibiting the time for reaction to thermal stimulus and it did not show any motor performance alterations [34].

\subsection{Antimicrobial Activity}

The essential oil of M. ovata leaves shows antimicrobial action against several microorganisms [13]. The studies of Alarcón and coworkers [26] showed that the essential oil of M. fallax flowers from Venezuela is active only against the Gram positive bacteria and not against the Gram negative bacteria. The oil from $M$. aff. fosteri showed activity against two bacteria which was comparable to chloramphenicol [27]. The leaves essential oils of M. myrtillifolia showed antimicrobial activity against several microorganisms, with a moderate toxicity against Artemia salina [30]. The essential oils of 
M. alagoensis exhibited a broad spectrum of antibacterial action, on both Gram positive and Gram negative bacteria, and the former were more sensitive to the essential oil from the fresh leaves [21]. Antibacterial activity was observed when essential oil from the stems of M. splendens was tested [37].

\subsection{Larvicidal Activity}

The essential oil of M. ovata leaves, which is rich in citral (neral: 35.8\%; geranial: 50.4\%), showed larvicidal activity against Aedes aegypti [32]. According to these authors the essential and their major compounds may be potent source of natural larvicides.

\subsection{Antiproliferative Activity}

The essential oil from $M$. laruotteana fruits and the fraction rich in $\alpha$-bisabolol when tested against in vivo human cancer cells (glioma, melanoma, breast, ovarian and ovarian-resistant, kidney, lung, prostate, colon and leukemia) showed antiproliferative activity against all cell lines, except for the lung cell line; the $\alpha$-bisabolol rich fraction had a similar profile [28].

\subsection{Antioxidant Capacity}

The essential oil from $M$. amazonica leaves showed a higher antioxidant activity than BHT (buthyl-hydroxytoluene) and $\alpha$-tocopherol when using the ORAC (oxygen radical absorbance capacity) method, but lower when the cation-radical ABTS (2,2'-azino-bis(3-ethylbenzthiazoline-6-sulfonic acid)) method was applied, using TROLOX as reference [22].

\section{Activity of the Major Compounds from Myrcia Essential Oils}

Some of the constituents of Myrcia essential oils show activities that could contribute to the biological properties, however, in all cases synergistic and antagonist influence of the various components should be considered.

Citral has a significant central and peripheral antinociceptive effect and anti-inflammatory activity [42]. In that way, citral, the major component of $M$. ovata essential oil, can contribute for the observed analgesic activity of the essential oil.

The sesquiterpene caryophyllene oxide exhibits antinociceptive activity [43]; the monoterpene 1,8-cineole also shows antinociceptive properties on hot plate and tail-flick tests, while $\beta$-pinene exerts supraspinal and antinociceptive actions in rats, but it reverses the effect of morphine [44]. These compounds were identified in several essential oils from Myrcia.

Terpinen-4-ol, linalool, $\alpha$-terpineol and $\beta$-caryophyllene are known for their antimicrobial activities $[45,46]$. These compounds probably contribute to some of the observed activities.

\section{Non-Volatiles}

The chemical studies regarding to the non-volatile compounds identified from Myrcia species mostly describe the isolation of flavonol glucosides. Together with flavonoids, terpenoids, organic acids, acetophenones and related compounds have been isolated. A small number of species have been studied for their chemical composition on non-volatile compounds. 


\subsection{Flavonoids}

The flavonoids isolated from Myrcia are mostly flavanones and flavonol-O-glycosides. The sugar units are usually galactose, glucose, xylose and rhamnose. Structures of the isolated flavonoids from Myrcia are in Figures 1-3.

The extracts of $M$. multiflora leaves contain the flavanone glucosides myrciacitrins I (1), II (2), III (3), IV (4) and V (5) [47,48]. To date, the flavanone glucosides have been isolated only from M. multiflora.

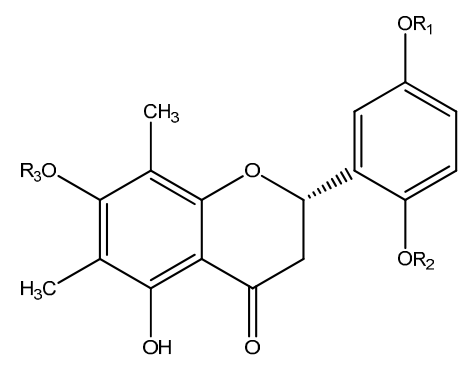

\begin{tabular}{cccc}
\hline Compound & $\mathbf{R}_{\mathbf{1}}$ & $\mathbf{R}_{\mathbf{2}}$ & $\mathbf{R}_{\mathbf{3}}$ \\
\hline $\mathbf{1}$ & $\mathrm{H}$ & $\mathrm{H}$ & $O-\beta$-D-glucopyranosyl \\
$\mathbf{2}$ & $\mathrm{CH}_{3}$ & $\mathrm{H}$ & $O-\beta$-D-glucopyranosyl \\
$\mathbf{3}$ & $\mathrm{H}$ & $O-\beta$-D-glucopyranosyl & $\mathrm{H}$ \\
$\mathbf{4}$ & $\mathrm{H}$ & $\mathrm{H}$ & $\left(6^{\prime \prime}-O-p\right.$-coumaroyl $)-O-\beta$-D-glucopyranosyl \\
$\mathbf{5}$ & $\mathrm{H}$ & $\mathrm{H}$ & $\left(6^{\prime \prime}-O-p\right.$-hydroxybenzoyl $)-O-\beta$-D-glucopyranosyl \\
\hline
\end{tabular}

Figure 1. Structures of the flavanone glucosides Myrciacitrins.

Myrcia multiflora extracts also contain the flavonol glucosides myricitrin (6), mearnsitrin (7), quercitrin (8), desmanthin-1 (9), guaijaverin (10) [47,48]. Myricitrin (6) was also isolated from M. bella Cambess. [49], M. splendens [50], M. palustris DC. [50] and M. uniflora [51], mearnsitrin (7) was also obtained from M. uniflora [52]. From the leaves of M. tomentosa, avicularin (11) and juglanin (12) were isolated [53]. Other flavonoids have been isolated from M. bella, such as myricetin (13), kaempferol-3$O$-deoxyhexoside (14), kaempferol-3-O-hexoside (15), myricetin-3-O- $\beta$-D-galactopyranoside (16), myricetin-3-O- $\alpha$-arabinofuranoside (17), myricetin-3- $O$ - $\alpha$-arabinopyranoside (18), myricetin-3-O- $(O$ galloyl)-hexoside (19), quercetin (20), quercetin-3-O- $\beta$-D-galactopyranoside (21), quercetin-3-O- $\beta$-Dxylofuranoside (22), quercetin-3- $O$ - $\beta$-D-xylopyranoside (23), quercetin-3- $O$ - $\alpha$-L-arabinofuranoside (24), quercetin-3- $O$-(6"-galloyl)- $\beta$-galactopyranoside (25), quercetin-3- $O$-( $O$-galloyl)-pentoside (26) [49]. Myrcia palustris also produced desmanthin-1 (9), myricetin (13), myricetin-3-O- $\beta$-D-galactopyranoside (16), quercetin (20), quercetin-3-O- $\beta$-D-xylopyranoside (23) and quercetin-3- $O$ - $\alpha$-L-arabinofuranoside (24) together with myricetin-(6"-galloyl)-3-O- $\beta$-D-galactopyranoside (27), myricetin-3-O- $\beta$-Dxylopyranoside (28), quercetin-3- $O$ - $\alpha$-L-arabinopyranoside (29), quercetin-3- $O$ - $\alpha$-L-rhamnopyranoside (30) and kaempferol-3-O- $\beta$-D-galactopyranoside (31) [54]. Quercetin (20) was also isolated from M. myrtillifolia [55]. Flavonol glucoside is the major class of non-volatile secondary metabolites identified from Myrcia species. 
<smiles>[2H]c1c(-c2cc(Br)c(O)c(Br)c2)oc2cc(O)cc(O)c2c1=O</smiles>

\begin{tabular}{|c|c|c|c|c|}
\hline Compound & $\mathbf{R}_{1}$ & $\mathbf{R}_{\mathbf{2}}$ & $\mathbf{R}_{\mathbf{3}}$ & $\mathbf{R}_{\mathbf{4}}$ \\
\hline 6 & $\mathrm{OH}$ & $\mathrm{H}$ & $\mathrm{OH}$ & $O$ - $\alpha$-L-rhamnopyranosyl \\
\hline 7 & $\mathrm{OH}$ & $\mathrm{CH}_{3}$ & $\mathrm{OH}$ & $O-\alpha$-L-rhamnopyranosyl \\
\hline 8 & $\mathrm{OH}$ & $\mathrm{H}$ & $\mathrm{OH}$ & $O$ - $\alpha$-L-rhamnopyranosyl \\
\hline 9 & $\mathrm{OH}$ & $\mathrm{H}$ & $\mathrm{OH}$ & (2"-O-galloyl)-O- $\alpha$-L-rhamnopiranosyl \\
\hline 10 & $\mathrm{OH}$ & $\mathrm{H}$ & $\mathrm{H}$ & $O$ - $\alpha$-L-arabinopyranosyl \\
\hline 11 & $\mathrm{OH}$ & $\mathrm{H}$ & $\mathrm{H}$ & $O$ - $\alpha$-L-arabinofuranosyl \\
\hline 12 & $\mathrm{H}$ & $\mathrm{H}$ & $\mathrm{H}$ & $O-\alpha$-L-arabinofuranosyl \\
\hline 13 & $\mathrm{OH}$ & $\mathrm{H}$ & $\mathrm{OH}$ & $\mathrm{OH}$ \\
\hline 14 & $\mathrm{H}$ & $\mathrm{H}$ & $\mathrm{H}$ & $O$-Deoxyhexosyl \\
\hline 15 & $\mathrm{H}$ & $\mathrm{H}$ & $\mathrm{H}$ & O-Hexosyl \\
\hline 16 & $\mathrm{OH}$ & $\mathrm{H}$ & $\mathrm{OH}$ & $O-\beta$-D-galactopyranosyl \\
\hline 17 & $\mathrm{OH}$ & $\mathrm{H}$ & $\mathrm{OH}$ & $O$ - $\alpha$-arabinofuranosyl \\
\hline 18 & $\mathrm{OH}$ & $\mathrm{H}$ & $\mathrm{OH}$ & $O$ - $\alpha$-arabinopyranosyl \\
\hline 19 & $\mathrm{OH}$ & $\mathrm{H}$ & $\mathrm{OH}$ & (O-galloyl)-O-hexosyl \\
\hline 20 & $\mathrm{H}$ & $\mathrm{H}$ & $\mathrm{OH}$ & $\mathrm{OH}$ \\
\hline 21 & $\mathrm{H}$ & $\mathrm{H}$ & $\mathrm{OH}$ & $O-\beta$-D-galactopyranosyl \\
\hline 22 & $\mathrm{H}$ & $\mathrm{H}$ & $\mathrm{OH}$ & $O$ - $\beta$-D-xylofuranosyl \\
\hline 23 & $\mathrm{H}$ & $\mathrm{H}$ & $\mathrm{OH}$ & $O-\beta$-D-xylopyranosyl \\
\hline 24 & $\mathrm{H}$ & $\mathrm{H}$ & $\mathrm{OH}$ & $O-\alpha$-L-arabinofuranosyl \\
\hline 25 & $\mathrm{H}$ & $\mathrm{H}$ & $\mathrm{OH}$ & (6"-O-galloyl)-O- $\beta$-galactopyranosyl \\
\hline 26 & $\mathrm{H}$ & $\mathrm{H}$ & $\mathrm{OH}$ & $(O$-galloyl)-pentosyl \\
\hline 27 & $\mathrm{OH}$ & $\mathrm{H}$ & $\mathrm{OH}$ & (6"-O-galloyl)-O- $\beta$-D-galactopyranosyl \\
\hline 28 & $\mathrm{OH}$ & $\mathrm{H}$ & $\mathrm{OH}$ & $O$ - $\beta$-D-xylopyranosyl \\
\hline 29 & $\mathrm{H}$ & $\mathrm{H}$ & $\mathrm{OH}$ & $O-\alpha$-L-arabinopyranosyl \\
\hline 30 & $\mathrm{H}$ & $\mathrm{H}$ & $\mathrm{OH}$ & $O-\alpha$-L-rhamnopyranosyl \\
\hline 31 & $\mathrm{H}$ & $\mathrm{H}$ & $\mathrm{H}$ & $O-\beta$-D-galactopyranosyl \\
\hline
\end{tabular}

Figure 2. Structures of the flavonols and their glucosides isolated from Myrcia.

Studies with the leaves of $M$. hiemalis Cambess. led to the isolation of 5-hydroxy-6,8dimethyl-7-methoxyflavanone (32), 6,8-dimethyl-5,7-dimethoxyflavanone (33) and 2,7-dihydroxy-6,8dimethyl-5-methoxyflavanone (34), together with the chalcones $2^{\prime}, 4^{\prime}$-dihydroxy-3',5'-dimethyl-4,6'dimethoxychalcone (35), 2'-hydroxy-3',5'-dimethyl-4',6'-dimethoxychalcone (36) and 2',6'-dihydroxy3',5'-dimethyl-4'-methoxychalcone (37) and the isoflavone 7-hydroxy-6,8-dimethyl-5-methoxyisoflavone (38) [55]. Myrcia hiemalis was the only species from which chalcones, C-methylflavanones and isoflavones were isolated. 
<smiles>Cc1c(C)c2c(c([N+](=O)[O-])c1C)C(=O)C[C@@](C)(c1ccccc1)O2</smiles>

\begin{tabular}{cccc}
\hline Compound & $\mathbf{R}_{\mathbf{1}}$ & $\mathbf{R}_{\mathbf{2}}$ & $\mathbf{R}_{\mathbf{3}}$ \\
\hline $\mathbf{3 2}$ & $\mathrm{H}$ & $\mathrm{CH}_{3}$ & $\mathrm{H}$ \\
$\mathbf{3 3}$ & $\mathrm{H}$ & $\mathrm{CH}_{3}$ & $\mathrm{CH}_{3}$ \\
$\mathbf{3 4}$ & $\mathrm{OH}$ & $\mathrm{H}$ & $\mathrm{CH}_{3}$ \\
\hline
\end{tabular}<smiles>Cc1c(O)c(C)c(O)c(C(=O)/C=C/c2ccc(Br)cc2)c1O</smiles>

\begin{tabular}{cccc}
\hline Compound & $\mathbf{R}_{\mathbf{1}}$ & $\mathbf{R}_{\mathbf{2}}$ & $\mathbf{R}_{\mathbf{3}}$ \\
\hline $\mathbf{3 5}$ & $\mathrm{OCH}_{3}$ & $\mathrm{CH}_{3}$ & $\mathrm{H}$ \\
$\mathbf{3 6}$ & $\mathrm{H}$ & $\mathrm{CH}_{3}$ & $\mathrm{CH}_{3}$ \\
$\mathbf{3 7}$ & $\mathrm{H}$ & $\mathrm{H}$ & $\mathrm{CH}_{3}$ \\
\hline
\end{tabular}<smiles>COc1c(C)c(O)c(C)c2occ(-c3ccccc3)c(=O)c12</smiles>

38

Figure 3. Other flavonoids and derivatives isolated from Myrcia species.

\subsection{Terpenoids}

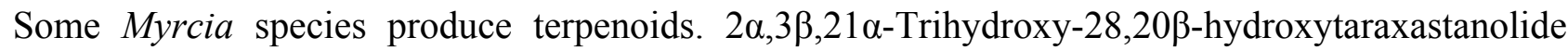
(39) was isolated from M. hiemalis [55], and betulinic acid (40), betulonic acid (41), betulinaldehyde (42), betulona (43), oleanolic acid (44), ursolic acid (45) were obtained from M. myrtillifolia [55]. The sesqui-, di- and tetraterpenoids eudesm-4-(15)-en-7 $\alpha, 11$-diol (46) and geranylgeranyl acetate (47) and $\alpha$-tocopherol (48), respectively, were also isolated from M. hiemalis [55]. Stigmasterol (49) was found in M. myrtillifolia [55]. Structures of the terpenoids identified from Myrcia are in Figure 4. 


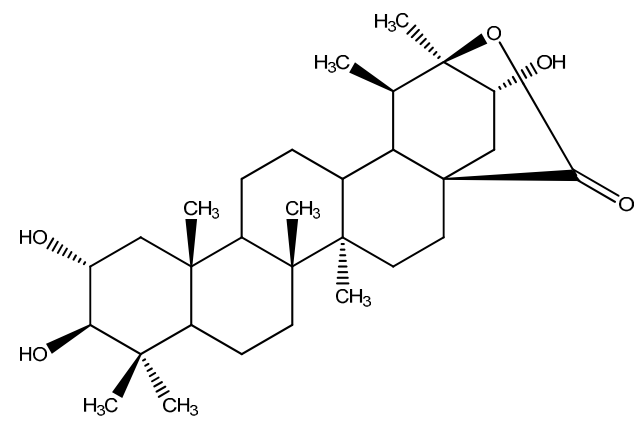

39

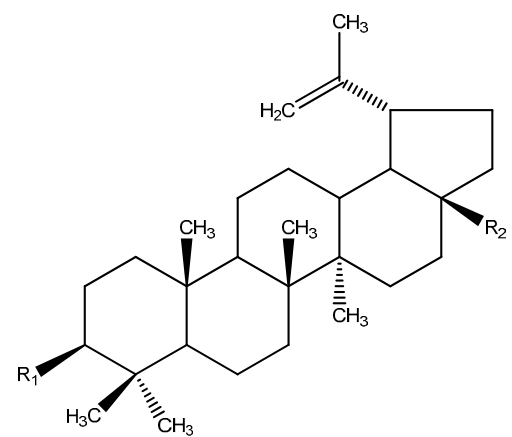

\begin{tabular}{ccc}
\hline Compound & $\mathbf{R}_{\mathbf{1}}$ & $\mathbf{R}_{\mathbf{2}}$ \\
\hline $\mathbf{4 0}$ & $\mathrm{OH}$ & $\mathrm{COOH}$ \\
$\mathbf{4 1}$ & $=\mathrm{O}$ & $\mathrm{COOH}$ \\
$\mathbf{4 2}$ & $\mathrm{OH}$ & $\mathrm{CHO}$ \\
$\mathbf{4 3}$ & $=\mathrm{O}$ & $\mathrm{CH}_{2} \mathrm{OH}$ \\
\hline
\end{tabular}

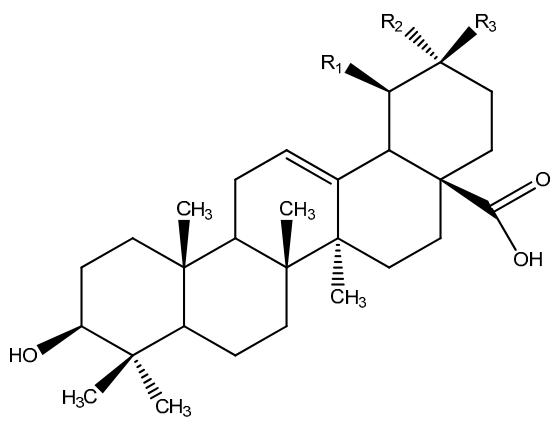

\begin{tabular}{cccc}
\hline Compound & $\mathbf{R}_{\mathbf{1}}$ & $\mathbf{R}_{\mathbf{2}}$ & $\mathbf{R}_{\mathbf{3}}$ \\
\hline $\mathbf{4 4}$ & $\mathrm{CH}_{3}$ & $\mathrm{CH}_{3}$ & $\mathrm{H}$ \\
$\mathbf{4 5}$ & $\mathrm{H}$ & $\mathrm{CH}_{3}$ & $\mathrm{CH} 3$ \\
\hline
\end{tabular}<smiles>C=C1CCC[C@]2(C)CCC[C@](O)(C(C)(C)O)C12</smiles>

Figure 4. Cont. 
<smiles>CC(=O)OC/C=C(\C)CC/C=C(\C)CC/C=C(\C)CCC=C(C)C</smiles><smiles>Cc1c(C)c2c(c(C)c1O)CC[C@@](C)(CCCC(C)CCCC(C)CCCC(C)C)O2</smiles><smiles>CC[C@H](/C=C/[C@H](C)C1CC[C@@H]2[C@]1(C)CC[C@@]1(C)[C@@]3(C)CC[C@H](O)CC3=CC[C@]21C)C(C)C</smiles>

Figure 4. Terpenoids from Myrcia species.

\subsection{Organic Acids}

Some organic acids were isolated from Myrcia species (Figure 5). Gallic acid (50) was isolated from the leaves of M. bella [49] and M. guianensis [56]. Protocatechuic acid (51) was identified from M. guianensis [56] and M. palustris [54]. Caffeic acid (52), quinic acid (53) and the derivative ethyl gallate (54) were found in M. bella [49]. Cinnamic acid (55) was isolated from M. hiemalis [55] and ginkgoic acid (56) from M. multiflora [47].<smiles>O=C(O)c1cc(O)c(O)c(O)c1</smiles>

50<smiles>O=C(O)c1ccc(O)c(O)c1</smiles>

51<smiles>O=C(O)/C=C/c1ccc(O)c(O)c1</smiles>

52<smiles>O=C(O)[C@]1(O)C[C@@H](O)[C@H](O)[C@H](O)C1</smiles>

53<smiles>CCOC(=O)c1cc(O)c(O)c(O)c1</smiles>

54<smiles>O=C(O)/C=C/c1ccccc1</smiles>

55<smiles>CCCCCC/C=C/CCCCCCCc1cccc(O)c1C(=O)O</smiles>

56

Figure 5. Organic acids isolated from Myrcia species. 


\subsection{Acetophenones and Related Compounds}

Myciaphenones A (57) and B (58) and phloroacetophenone (2', 4',6'-trihydroxyacetophenone) (59), were isolated from M. multiflora [47,57]; two derivatives (60-61) were identified in M. myrtillifolia [55]. Structures of compounds 57-61 are in Figure 6.<smiles>CC(=O)c1c(O)cc(O)cc1O</smiles>

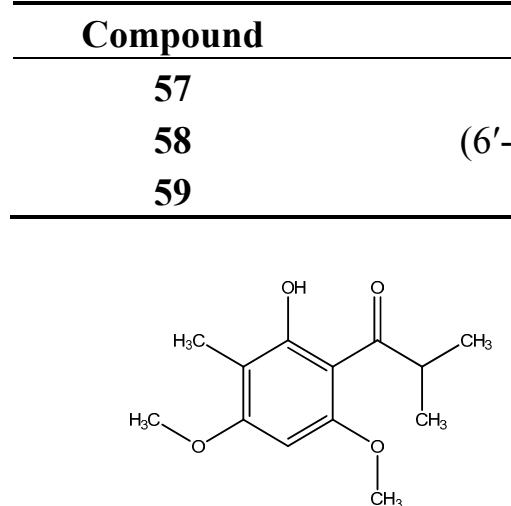

60<smiles>CCCC(=O)c1c(OC)cc(OC)c(C)c1O</smiles>

61

Figure 6. Acetophenones and derivatives from Myrcia species.

\subsection{Tannins}

Myrcia palustris produced the tannin casuarinin (62) together with 4-O-(4"-O-acetyl$\alpha$-L-rhamnopyranosyl)-ellagic acid (63), 4-O-(2",4"-O-diacetyl- $\alpha$-L-rhamnopyranosyl)-ellagic acid (64), 4-O-(2",3"-O-diacetyl- $\alpha$-L-rhamnopyranosyl)-ellagic acid (65), 4- $O$ - $\left(3^{\prime \prime}, 4\right.$ "'-O-diacetyl- $\alpha$-Lrhamnopyranosyl)-ellagic acid (66) and 4-O-(2",3",4"-O-triacetyl- $\alpha$-L-rhamnopyranosyl)-ellagic acid (67) [54]. Structures of the tannins identified from Myrcia species are in Figure 7.

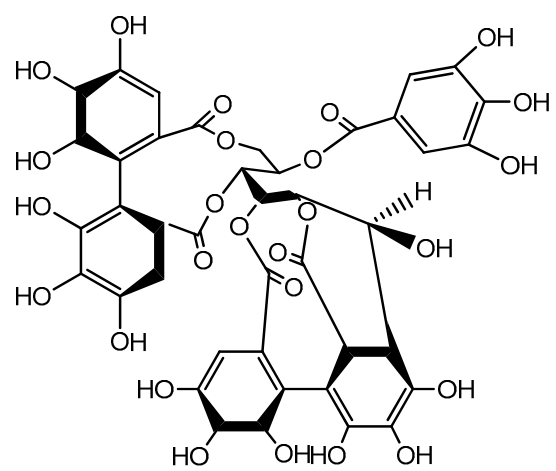

62

Figure 7. Cont. 


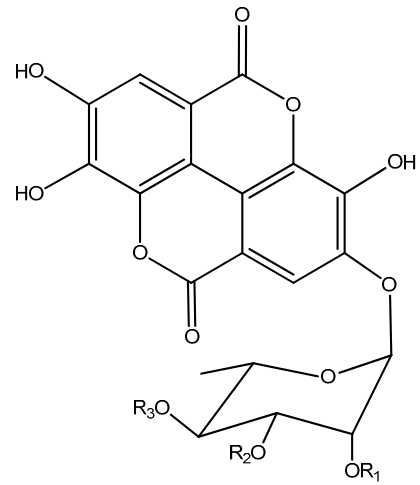

\begin{tabular}{cccc}
\hline Compound & $\mathbf{R}_{\mathbf{1}}$ & $\mathbf{R}_{\mathbf{2}}$ & $\mathbf{R}_{\mathbf{3}}$ \\
\hline $\mathbf{6 3}$ & $\mathrm{H}$ & $\mathrm{H}$ & Acetyl \\
$\mathbf{6 4}$ & Acetyl & H & Acetyl \\
$\mathbf{6 5}$ & Acetyl & Acetyl & H \\
$\mathbf{6 6}$ & H & Acetyl & Acetyl \\
$\mathbf{6 7}$ & Acetyl & Acetyl & Acetyl \\
\hline
\end{tabular}

Figure 7. Tannins isolated from Myrcia species.

\subsection{Alkaloid}

Myrcia blanchetiana (O.Berg) Mattos was the only Myrcia species found to produce alkaloid; the nicotinic ester Myrciaine (68) was identified from this species [58] (Figure 8).

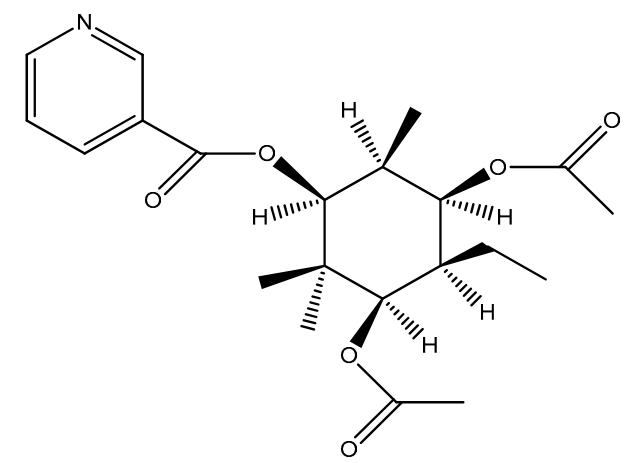

68

Figure 8. Strucuture of the alkaloid myrciaine.

\section{Pharmacological Effects of Myrcia Extracts and Isolated Compounds}

Several studies dealing with biological activities of Myrcia extracts and isolated compounds have been published.

\subsection{Hypoglycemic Potential}

The methanol extract and ethyl acetate-soluble portion from $M$. multiflora leaves, one of the species known as "pedra-ume-caá", showed inhibitory activities on aldose reductase and $\alpha$-glucosidase, on the increase of serum glucose level on sucrose-loaded rats and on alloxan-induced diabetic mice [47]. The 
flavanone glucosides myrciacitrins I-II (1-2), the flavonol glucosides myricitrin (6), mearnsitrin (7), quercetin (8), desmanthin-1 (9) and guaijaverin (10) and the acetophenone glucoside myrciaphenone B (58), all isolated from M. multiflora, showed potent inhibitory activity on aldose reductase and $\alpha$-glucosidase and among them, desmanthin-1 showed the most potent activity on aldose reductase [47]. A further study with the same species confirms potent inhibitory activity on aldose reductase of myrciatrins, including III, IV and V [48]. When comparing the structures of the tested substances, it is observed that desmanthin-1 is the only flavonol glucoside with a galloyl group linked to the sugar unit.

Myrcia palustris produced five $\alpha$-glucosidase inhibitors, the flavonol glucosides myricetin (13), quercetin (20), casuarinin (62), myricetin 3-O- $\beta$-D-(6"-galloyl)-galactopyranoside (27) and kaempferol 3-O- $\beta$-D-galactopyranoside (31) [54]. The treatment of mice with the ethanol extract of $M$. bella leaves using $600 \mathrm{mg} / \mathrm{kg}$ reduced the fast blood glucose, total cholesterol and triglycerides and it increased hepatic glycogen; the authors conclude that the tested extract has exhibited hypoglycemic properties and possibly acts to regulate glucose uptake by the liver [59]. Although M. palustris and M. bella are not included in the group as species known as "pedra-ume-caá", they show hypoglycemic potential.

The number of studies is still small, but it can be observed that flavonol glucosides and acethophenone derivatives are not restricted to species known as "pedra-ume-caá".

\subsection{Antiobesity and Mixed Hypolipidemic Effects}

Phloroacetophenone (59) isolated from M. multiflora has hypolipidemic and antiobesity effects related to reduction of triglyceride intestinal absorption and pancreatic lipase activity inhibition [57].

\subsection{Anti-Hemorrhagic Activity}

The aqueous extract and the aqueous residue at 1:1 (w/w) of the leaves of M. guianensis completely inhibited the hemorrhagic effect produced by intradermic injections of crude venom of the snake Bothrops jararaca in Swiss mice; the ethyl acetate extract at 1:3 (w/w) inhibited 90.7\%; the in vitro venom effect was analyzed by electrophoresis; according to the authors, these observations could explain the traditional use of M. guianensis to reduce snake venom effect [18].

\subsection{Phytotoxic Effect and Allelophatic Potential}

The ethyl acetate extract of $M$. guianensis leaves $(1 \% w / v)$ showed phytotoxic activity when tested on seed germination and seedlings growth bioassays using the weeds Mimosa pudica and Senna obtusifolia as test plants; the isolated compounds gallic (50) and protocatechuic acids (51) showed concentration-dependent allelopathic effects and the strongest activity was observed at $60 \mathrm{ppm}$ [56]. The fractions containing the flavonoids glucosides avicularin (11) and juglanin (12) isolated from M. tomentosa showed potent inhibition of coleoptiles growth using wheat seeds (Triticum aestivum) as the test plant [53]. 


\subsection{Hepatoprotective Effect}

Hydrolysis of phloroacetophenone glucoside (57), isolated from M. multiflora, gave its aglicone (59), which protected mouse liver from injury induced by $\mathrm{CCl}_{4}$, probably through its scavenging ability [60]. In the same study, it was observed that the pre-treatment with phloroacetophenone normalized the activities of antioxidant enzymes catalase, glutathione peroxidase, and superoxide dismutase, and increased the levels of reduced glutathione. In addition, it significantly prevented the elevation of serum enzymatic activities, as well as histological alteration.

\subsection{Antioxidant Effects}

The ethanol extracts of M. laruotteana and M. obtecta leaves showed antioxidant effects in the DPPH assays; these extracts were more active than quercetin [61]. The ethyl acetate and $n$-butanol phases of the hydroalcoholic extract of M. splendens and M. palustris leaves and stems showed antioxidant activity using DPPH radical and iron reduction assays; myricitrin (6) was isolated as the major constituent of the ethyl acetate phase of both species [50].

Studies with $M$. rostrata showed that the content of phenolic compounds (total, tannins, flavonoids) is influenced by environmental factors such as soil micronutrients, rainfall and $\mathrm{pH}$ [62], as well as the study with M. tomentosa leaves [63].

\subsection{Others}

The aqueous phase of the methanol extract of $M$. uniflora and the isolated flavonoids myricitrin (6) and mearnsitrin (7) were able to inhibit thyroid peroxidase in vitro; according to the authors, the indiscriminate consumption of M. uniflora pharmaceutical products (capsules or tinctures for treatment of diabetes mellitus), allied to the nutritional deficiency of iodine, might contribute to the development of hypothyroidism [52].

A US patent dealing with $M$. fallax extracts and its capacity of killing tumor cells derived from human carcinoma of the nasopharynx (KB) was deposited [64].

\section{Concluding Remarks}

Myrcia is an economically important genus. It is a rich source of essential oils and it is ornamental. Parts of the plant in natura, extracts and capsules of some Myrcia species are commercialized as phytomedicine. Myrcia species are used in the traditional medicine on the treatment of a variety of illnesses, including diabetes and stomach problems. The essential oils from Myrcia, are usually mixtures of sesquiterpenes with small concentrations of monoterpenes. These volatile oils have shown biological activities such as anti-inflammatory, antinociceptive, antimicrobial, among others. Chemical studies with the non-volatile compounds show that Myrcia species are a rich source of flavonoids, especially flavonol glucosides; triterpenoids, organic acids and acetophenone derivatives were also isolated from Myrcia. Some of the isolated flavonol and flavanone glucosides, their aglicones and acetophenone derivatives show hypoglycemic potential and could explain the traditional use of some of Myrcia species to treat diabetes. Acetophenone derivatives are also related to hypolipidemic effects. Therefore, Myrcia is a promising source of biologically active compounds. Several species have not been chemically and 
biologically studied, and others required further studies. As it is observed for other Myrtaceae, the similarity of the species is high and taxonomic and nomenclatural history is complex, resulting in difficulties in identification. Further comparison of chemical composition, biological activities and traditional uses taking into account all species of Myrcia s.l. will contribute to the chemosystematic of Myrtaceae.

\section{Acknowledgments}

The authors would like to thank Coordenação de Aperfeiçoamento de Pessoal de Nível Superior (CAPES) for fellowship (Márcia Moraes Cascaes).

\section{Author Contributions}

All authors helped preparing the manuscript and approved the final version. Marcia Moraes Cascaes, Giselle Maria Skelding Pinheiro Guilhon and Maria das Graças Bichara Zoghbi were responsible for organizing and writing the manuscript. Marcia Moraes Cascaes, Giselle Maria Skelding Pinheiro Guilhon and Lourivaldo da Silva Santos carried out the research regarding the non-volatiles and traditional uses. Maria das Graças Bichara Zoghbi and Eloisa Helena de Aguiar Andrade were responsible for the research related to the volatiles.

\section{Conflicts of Interest}

The authors declare no conflict of interest.

\section{References}

1. Govaerts, R.; Sobral, M.; Ashton, P.; Barrie, F.; Holst, B.K.; Landrum, L.L.; Matsumoto, K.; Mazine, F.F.; Nic Lughadha, E.; Proença, C.; et al. Word Checklist of Myrtaceae; Kew Publishing, Royal Botanic Gardens: Kew, UK, 2014.

2. Sobral, M.; Proença, C.; Souza, M.; Mazine, F.; Lucas, E. Myrtaceae in Lista de Espécies da Flora do Brasil (List of species from Brazil's flora). Jardim Botânico do Rio de Janeiro. Available online: http://reflora.jbrj.gov.br/jabot/floradobrasil/FB10660 (accessed on 7 July 2015).

3. Landrum, L.R.; Kawasaki, M.L. The genera of Myrtaceae in Brazil: An illustrate synoptic treatment and identification keys. Brittonia 1997, 49, 508-536.

4. Souza, V.C.; Lorenzi, H. Botânica Sistemática: Guia Ilustrado para Identificação das Famílias de Fanerógamas Nativas e Exóticas no Brasil, Baseado no APG II (Systematic Botany: Illustrated Guide for the Identification of Native and Exotic Phanerogams in Brazil, Based on APG II), 2nd ed.; Instituto Plantarum: Nova Odessa, Brazil, 2008; pp. 297-302.

5. Cruz, A.V.M.; Kaplan, M.A.C. Uso medicinal de espécies das famílias Myrtaceae e Melastomataceae no Brasil (Medicinal use of Myrtaceae and Melastomataceae species in Brazil). Floresta Ambient. 2004, 11, 47-52.

6. Lucas, E.J.; Matsumoto, K.; Harris, S.A.; Nic Lughadha, E.M.; Benardini, B.; Chase, M.W. Phylogenetics, morphology, and evolution of the large genus Myrcia s.l. (Myrtaceae). Int. J. Plant Sci. 2011, 172, 915-934. 
7. Staggemeier, V.G.; Diniz-Filho, J.A.F.; Forest, F.; Lucas, E. Phylogenetic analysis in Myrcia section Aulomyrcia and inferences on plant diversity in the Atlantic rainforest. Ann. Bot. 2015, doi:10.1093/aob/mcv005.

8. Staggemeier, V.G.; Diniz-Filho, J.A.F.; Zipparro, V.B.; Gressler, E.; Castro, E.R.; Mazine, F.; Costa, I.R.; Lucas, E.; Morellato, L.P. Clade-specific responses regulate phenological patterns in Neotropical Myrtaceae. Perspect. Plant Ecol. Evol. Syst. 2015, doi:10.1016/j.ppees.2015.07.004.

9. Rosario, A.S.; Baumgratz, J.F.A.; Secco, R.S. Contribuição à taxonomia de Marlierea (Mirciinae; Myrtaceae) no Brasil (Contribution to the taxonomy of Marlierea (Mirciinae; Myrthaceae) in Brazil). Rodriguesia 2014, 1, 245-250.

10. Le Cointe, P. A Amazônia Brasileira III: Árvores e Plantas Úteis (Indígenas e Aclimatadas) (Brazilian Amazon III: Useful Trees and Plants (Natives and Acclimatized)); Livraria Clássica: Belém, Brazil, 1934; p. 366.

11. Coimbra, R. Manual de Fitoterapia (Manual of Phytotherapy), 2nd ed.; Editora Cejup: Belém, Brazil, 1994; p. 219.

12. Cruz, G.L. Dicionários de Plantas Úteis do Brasil (Dictionary of Useful Plants from Brazil), 5th ed.; Bertrand Brasil: Rio de Janeiro, Brazil, 1995; p. 498.

13. Van den Berg, M.E. Plantas Medicinais na Amazônia: Contribuição ao Seu Conhecimento Sistemático (Medicinal Plants in the Amazon: Contribution to Its Systematic Knowledge), 3rd ed.; Museu Paraense Emílio Goeldi, Coleção Adolpho Ducke: Belém, Brazil, 2010; p. 220.

14. Silva, F.K.S.; Rosário, A.S.; Secco, R.S.; Zoghbi, M.G.B. Levantamento das espécies conhecidas como pedra-ume-caá (Myrtaceae), com ênfase nas comercializadas na cidade de Belém, Pará, Brasil (Survey of the species known as pedra-ume-caá (Myrtaceae), with emphasis of those commercialized in the city of Belém, Pará, Brazil). Biota Amazôn. 2015, 5, 7-15.

15. Jorge, L.I.F.; Aguiar, J.P.L.; Silva, M.L.P. Anatomia foliar de pedra-ume-caá (Myrcia sphaerocarpa, Myrcia guianensis, Eugenia punicifolia-Myrtaceae) (Leaf anatomy of pedra-ume-caá (Myrcia sphaerocarpa, Myrcia guianensis, Eugenia punicifolia-Myrtaceae)]. Acta Amazon. 2000, 30, 49-57.

16. Santos, E.B.; Dantas, G.S.; Santos, H.B.; Diniz, M.F.F.M.; Sampaio, F.C. Estudo etnobotânico de plantas medicinais para problemas bucais no município de João Pessoa, Brasil (Ethnobotanical study of medicinal plants for mouth diseases in the municipality of João Pessoa, Brazil). Braz. J. Pharmacogn. 2009, 19, 321-324.

17. Cândido, C.S.; Portella, C.S.A.; Laranjeira, B.J.; Silva, S.S.; Arriaga, A.M.C.; Santiago, G.M.P.; Gomes, G.A.; Almeida, P.C.; Carvalho, C.B.M. Effects of Myrcia ovata Cambess. essential oil on planktonic growth of gastrointestinal microorganisms and biofilm formation of Enterococcus faecalis. Braz. J. Microbiol. 2010, 41, 621-627.

18. Sousa, L.A.F.; Moura, V.M.; Raposo, J.D.A.; Sousa, L.F.; Oliveira, R.B.; Santos, L.S.; Araújo, R.N.M.; Silva, A.M.M.; Aranha, E.P.; Suemitsu, C.; et al. The effect of the aqueous extract of Myrcia guianensis (Aubl) DC and its fractions against the hemorrhagic activity of Bothrops jararaca venom. J. Med. Plants Res. 2013, 7, 3139-3146.

19. Stefanello, M.E.A.; Pascoal, A.C.R.F.; Salvador, M.J. Essential oils from Neotropical Myrtaceae: Chemical diversity and biological properties. Chem. Biodivers. 2011, 8, 73-94. 
20. Henriques, A.T.; Sobral, M.; Bridi, R.; Vérin, P.; Menut, C.; Lamarty, G.; Bessière, J.M. Essential oils from five Southern Brazilian species of Myrcia (Myrtaceae). J. Essent. Oil Res. 1997, 9 , $13-18$.

21. Silva, A.N.; Uetanabaro, A.P.T.; Lucchese, A.M. Chemical composition and antibacterial activity of essential oils from Myrcia alagoensis (Myrtaceae). Nat. Prod. Commun. 2013, 8, 269-271.

22. Calao, V.Y.P. Caracterização físico-química, composição e capacidade antioxidante do óleo essencial de Myrcia amazonica DC. (Myrtaceae) (Physical-chemical characterization, composition and antioxidant capacity of the essential oil of Myrcia amazonica DC. (Myrthaceae)). Master's Thesis, Universidade Federal do Oeste do Pará, Santarém, Brazil, April 2014.

23. Limberger, R.P.; Sobral, M.; Henriques, A.T.; Menut, C.; Bressière, J.M. Óleos voláteis de espécies de Myrcia nativas do Rio Grande do Sul (Volatile oils of Myrcia species native of Rio Grande do Sul). Quím. Nova 2004, 27, 916-919.

24. Pereira, R.A.; Zoghbi, M.G.B.; Bastos, M.N.C. Essential oils of twelve species of Myrtaceae growing wild in the sandbank of the Resex Maracanã, State of Pará, Brazil. J. Essent. Oil Bear. Plants 2010, $13,440-450$.

25. Zoghbi, M.G.B.; Andrade, E.H.A.; Silva, M.H.L.; Carreira, L.M.M.; Maia, J.G.S. Essential oils from three Myrcia species. Flavour Fragr. J. 2003, 8, 421-424.

26. Alarcón, L.D.; Peña, A.E.; Gonzales C.N.; Quintero, A.; Meza, M.; Usubillaga, A.; Velasco, J. Composition and antibacterial activity of the essential oil of Myrcia falax (Rich.) DC. from Venezuela. Rev. Soc. Quím. Perú 2009, 75, 221-227.

27. Tenorio, A.I.S.; Vargas, D.; Espinosa, A.; Diaz, A.; Gupta, M.P. Chemical composition of leaf essential oils of Calyptranthes microphylla B. Holts \& M.L, Myrcia aff fosteri Croat and Eugenia octopleura Krug \& Urb from Panama. J. Essent. Oil Res. 2011, 23, 29-33.

28. Stefanello, M.E.A.; Riva, D.; Simionatto, E.L.; Carvalho, J.E.; Ruiz, A.L.T.G.; Salvador, M.J. Chemical composition and cytotoxic activity of essential oil from Myrcia laruotteana fruits. J. Essent. Oil Res. 2011, 23, 7-10.

29. Stefanello, M.E.A.; Cervi, A.C.; Wisniewski, A., Jr.; Simionatto, E.L. Essential oil composition of Myrcia laruotteana Camb. J. Essent. Oil Res. 2007, 19, 466-467.

30. Cerqueira, M.D.; Souza-Neta, L.C.; Passos, M.G.V.M.; Lima, E.O.; Roque, N.F.; Martins, D.; Guedes, M.L.S.; Cruz, F.G. Seasonal variation and antimicrobial activity of Myrcia myrtifolia essential oils. J. Braz. Chem. Soc. 2007, 18, 998-1003.

31. Stefanello, M.E.A.; Cervi, A.C.; Wisniewski, A., Jr.; Simionattto, E.L. Composição e variação sazonal do óleo essencial de Myrcia obtecta (O.Berg) Kiaersk. var. obtecta, Myrtaceae (Composition and seasonal variation of the essential oil of Myrcia obtecta (O.Berg) Kiaersk. var. obtecta, Myrtaceae). Braz. J. Pharmacogn. 2010, 20, 82-86.

32. Lima, M.A.A.; Oliveira, F.F.M.; Gomes, G.A.; Lavor, P.L.; Santiago, G.M.P.; Nagao-Dias, A.T.; Arriaga, A.M.C.; Lemos, T.L.G.; Carvalho, M.G. Evaluation of larvicidal activity of the essential oils of plants from Brazil against Aedes aegypti (Diptera: Culicidae). Afr. J. Biotechnol. 2011, 10, 11716-11720.

33. Santos, G.C.M.; Gomes, G.A.; Gonçalves, G.M.; Sousa, L.M.; Santiago, G.M.P.; Carvalho, M.G.; Marinho, B.G. Essential oil from Myrcia ovata: Chemical composition, antinociceptive and anti-inflammatory properties in mice. Planta Med. 2014, 80, 1588-1596. 
34. Andrade, G.S.; Guimarães, A.G.; Santana, M.T.; Siqueira, R.S.; Passos, L.O.; Machado, S.M.F.; Ribeiro, A.S.; Sobral, M.; Almeida, J.R.G.S.; Quintans-Júnior, L.J. Phytochemical screening, antinociceptive and anti-inflammatory effects of the essential oil of Myrcia pubiflora in mice. Braz. J. Pharmacogn. 2012, 22, 181-188.

35. Cerqueira, M.D.; Marques, E.J.; Martins, D.; Roque, N.F.; Cruz, F.G. Variação sazonal da composição do óleo essencial de Myrcia salzmannii Berg (Myrtaceae) (Seasonal variation of the chemical composition of the esssential oil of Myrcia salzmannii Berg (Myrtaceae)). Quím. Nova 2009, 32, 1544-1548.

36. Nakamura, M.J.; Monteiro, S.S.; Bizarri, C.H.B.; Siani, A.C.; Ramos, M.F.S. Essential oils of four Myrtaceae species from the Brazilian southeast. Biochem. Sys. Ecol. 2010, 38, 1170-1175.

37. Jiménez, D.; Araque, M.; Rojas, L.; Cordero, A.; Briceño, B. Componentes volátiles y actividad antibacteriana del vástago de Myrcia splendens (Sw.) DC. (Volatiles and antibacterial activity of the stems of Myrcia splendens (Sw.) DC.). Rev. Fac. Farm. 2012, 54, 7-11.

38. Cole, R.A.; Haber, W.A.; Setzer, W.N. The leaf oil composition of Myrcia splendens from Monteverde, Costa Rica. J. Essent. Oil Bear. Plants 2008, 11, 41-44.

39. Sá, F.A.S.; Borges, L.L.; Paula, J.A.M.; Sampaio, B.L.; Ferri, P.H.; Paula, J.R. Essential oils in aerial parts of Myrcia tomentosa: Composition and variability. Braz. J. Pharmacogn. 2012, 22, 1233-1240.

40. Borges, L.L.; Alves, S.F.; Bara, M.T.F.; Conceição, E.C.; Herri, P.H.; Paula, J.R. Influence of environmental factors on the composition of essential oils from leaves of Myrcia tomentosa (Aubl.) DC. Bol. Latinoam. Caribe Plant. Med. Aromat. 2013, 12, 572-580.

41. Siani, A.C.; Azevedo, M.B.M.; Ramos, M.F.S.; Trigo, J.R. Monoterpenes and sesquiterpenes of Neotropical Myrtaceae. In Current Trends in Phytochemistry; Epifano, F., Ed.; Research Signpost: Kerala, India, 2008; pp. 223-251.

42. Quintans-Júnior, L.J.; Guimarães, A.G.; Santana, M.T.; Araújo, B.E.S.; Moreira, F.V.; Bonjardim, L.R.; Araújo, A.A.S.; Siqueira, J.S.; Antoniolli, A.R.; Botelho, M.A.; et al. Citral reduces nociceptive and inflammatory response in rodents. Rev. Bras. Plantas Med. 2011, 21, 497-502.

43. Chavan, M.J.; Wakte, P.S.; Shinde, D.B. Analgesic and anti-inflammatory activity of caryophyllene oxide from Annona squamosal L. bark. Phytomedicine 2010, 17, 149-151.

44. Liapi, C.; Anifantis, G.; Chinou, I.; Kourounakis, A.P.; Thedosopoulus, S.; Galanopoulou, P. Antinociceptive properties of 1,8-cineole and $\beta$-pinene, from the essential oil of Eucalyptus camaldulensis leaves, in rodents. Planta Med. 2007, 73, 1274-1254.

45. Huang, M.; Sanchez-Moreiras, A.M.; Abel, C.; Sohrabi, R.; Lee, S.; Gershenzon, J.; Tholl, D. The major volatile organic compound emitted from Arabidopsis thaliana, the sesquiterpene $\beta$-caryophyllene, is a defense against a bacterial pathogen. New Phytol. 2012, 193, 997-1008.

46. Lang, G.; Buchbauer, G. A review on recent research results (2008-2010) on essential oils as antimicrobials and antifungals. A review. Flavour Fragr. J. 2012, 27, 13-39.

47. Yoshikawa, M.; Shimada, H.; Nishida, N.; Li, Y.; Togushida, I.; Yamahara, J.; Matsuda, H. Antidiabetic principles of natural medicines. II. Aldose reductase and $\alpha$-glucosidase inhibitors from Brazilian natural medicine, the leaves of Myrcia multiflora DC. (Myrtaceae): Structures of Myrciacitrins I and II and Myrciaphenones A and B. Chem. Pharm. Bull. 1998, 46, 113-119. 
48. Matsuda, H.; Nishida, N.; Yoshikawa, M. Antidiabetic principles of natural medicines. V. Aldose reductase inhibitors from Myrcia multiflora DC. (2): Structures of Myrciacitrins III, VI and V. Chem. Pharm. Bull. 2002, 50, 429-431.

49. Saldanha, L.L.; Vilega, W.; Dokkedal, A.L. Characterization of flavonoids and phenolic acids in Myrcia bella Cambess. Using FIA-ESI-IT-MS ${ }^{\mathrm{n}}$ and HPLC-PAD-ESI-IT-MS combined with NMR. Molecules 2013, 18, 8402-8416.

50. Moresco, H.H.; Pereira, M.; Bretanha, L.C.; Micke, G.A.; Pizzolatti, M.G.; Brighente, I.M.C. Myricitrin as the main constituent of two species of Myrcia. J. Appl. Pharm. Sci. 2014, 4, 1-7.

51. Batista, A.N.L.; Colombo, R.; Pascoli, I.C.; Teles, H.L.; Silva, G.H.; Bomfim, G.C.C.; Burgos, R.C.R.; Cavalheiro, A.J.; Bolzani, V.S.; Silva, D.H.S; et al. Development and validation of a HPLC method for standardization of herbal and commercial extracts of Myrcia uniflora. Braz. J. Pharmacogn. 2011, 21, 402-406.

52. Ferreira, A.C.F.; Neto, J.C.; Silva, A.C.M.; Kuster, R.M.; Carvalho, D.P. Inhibition of thyroid peroxidase by Myrcia uniflora flavonoids. Chem. Res. Toxicol. 2006, 19, 351-355.

53. Imatomi, M.; Novaes, P.; Matos, A.P.; Gualtieri, S.C.J.; Molinillo, J.M.G.; Lacret, R.; Varela. R.M.; Macías, F.A. Phytotoxic effect of bioactive compounds isolated from Myrcia tomentosa (Myrtaceae) leaves. Biochem. Sys. Ecol. 2013, 46, 29-35.

54. Wubshet, S.G.; Moresco, H.H.; Tahtah, Y.; Brighente, I.M.C.; Staerk, D. High-resolution bioactivity profiling combined with HPLC-HRMS-SPE-NMR: $\alpha$-Glucosidase inhibitors and acetylated ellagic acid rhamnosides from Myrcia palustris DC. (Myrtaceae). Phytochemistry 2015, doi:10.1016/j.phytochem.2015.04.004.

55. Silva, P.D. Compostos fenólicos e terpenos de Myrcia hiemalis e Myrcia myrtifolia (Myrtaceae) (Phenolics and terpenes from Myrcia hiemalis and Myrcia myrtifolia (Myrtaceae)). Ph.D. Thesis, Universidade Federal da Bahia, Instituto de Química, Salvador, Brazil, 2012.

56. Souza Filho, A.P.S.; Santos, R.A.; Santos, L.S.; Guilhon, G.M.P.; Santos A.S.; Arruda, M.S.P.; Muller, A.H.; Arruda, A.C. Allelophatic potential of Myrcia guianensis. Planta Daninha 2006, 24, 649-656.

57. Ferreira, E.A.; Gris, E.F.; Rebello, J.M.; Correia, J.S.G.; Oliveira, L.F.S.; Wilhelm Filho, D.; Pedrosa, R.C. The 2',4',6'-trihydroxyacetophenone isolated from Myrcia multiflora has antiobesity and mixed hypolipidemic effects with the reduction of lipid intestinal absorption. Planta Med. 2011, 77, 1569-1574.

58. Cerqueira, M.D.; Souza-Neta, L.C.; Guedes, M.L.S.; Rivelino, R.; Cruz, F.G. Myrciaine, a new nicotinic ester from Myrcia blanchetiana (Myrtaceae). Tetrahedron Lett. 2013, 54, 1421-1423.

59. Vareda, P.M.P.; Saldanha, L.L.; Camaforte, N.A.P.; Violato, N.M.; Dokkedal A.L.; Bosqueiro, J.R. Myrcia bella leaf extract presents hypoglycemic activity via PI3k/Akt insulin signaling pathway. Evid. Based Complement. Alternat. Med. 2014, doi:10.1155/2014/543606.

60. Ferreira, E.A.; Gris, E.F.; Felipe, K.B.; Correia, J.S.G.; Cargnin-Ferreira, E.; Wilhelm Filho, D.; Pedrosa, R.C. Potent hepatoprotective effect in $\mathrm{CCl}_{4}$-induced hepatic injury in mice of phloroacetophenone from Myrcia multiflora. Lybian J. Med. 2010, doi:10.3402/ljm.v5i0.4891.

61. Salvador, M.J.; Lourenço, C.C.; Andreazza, N.L.; Pascoal, A.C.R.F.; Stefanello, M.E.A. Antioxidant capacity and phenolic content of four Myrtaceae plants of the South of Brazil. Nat. Prod. Commun. 2011, 6, 977-982. 
62. Alcântara, G.A.; Borges, L.L.; Paula, J.R. Seasonal variation in the content of phenolic compounds in barks of Myrcia rostrata DC. by influence of environmental factors. J. Pharm. Res. 2012, 5, 1306-1309.

63. Borges, L.L.; Alves, S.F.; Sampaio, B.L.; Conceição, E.C.; Bara, M.T.F.B.; Paula, J.R. Environmental factors affecting the concentration of phenolic compounds in Myrcia tomentosa leaves. Braz. J. Pharmacogn. 2013, 23, 230-238.

64. Hecht, S.M. Biologically Active Extracts from Myrcia fallax (Myrtaceae) Peru and Method of Obtaining the Same. U.S. Patent 4,451,459, 23 July 1982.

(C) 2015 by the authors; licensee MDPI, Basel, Switzerland. This article is an open access article distributed under the terms and conditions of the Creative Commons Attribution license (http://creativecommons.org/licenses/by/4.0/). 